\title{
Como se a ficção de fato desviasse rios
}

As if fiction in fact

diverted the rivers

Dennis Radünz

UFSC

\footnotetext{
r e $v$ s

t a d e I

i t e r a

u $r a$

o u t r a

t $r$ a e

s s i a
} 


\section{Resumo}

O naturalista Fritz Müller publicou o artigo "Der Minhocão", em 1877, na revista alemã Zoologische Garten, coletando depoimentos sobre o anelídeo descomunal que teria sido avistado nos estados de Santa Catarina, Paraná e São Paulo. Objeto desta leitura, o relato científico oitocentista é lido a partir da teoria do deslocamento das ideias de Filosofia do como se (Philosophie des Als Ob, 1911), de Hans Vaihinger, com elementos de Wolfgang Iser (fictício, imaginário) e Vilém Flusser (fábula filosófica Vampyrotheutis Infernalis). Nessa leitura, descrições de zoologia alterna de Guimarães Rosa e Wilson Bueno, um poema de Fritz Müller e fragmento de Galáxias, de Haroldo de Campos, são contrapontos que exploram lindes entre ficção e fato, entre ficção, hipótese e dogma científico.

Palavras-chave: Fritz Müller; Filosofia do Como Se; ciência; ficção; zoologia imaginária

\section{Abstract}

The naturalist Fritz Müller published the article "Der Minhocão", in 1877, in the German magazine Zoologische Garten, collecting testimonies about the inusual annelid that would have been seen in the states of Santa Catarina, Paraná and São Paulo. Object this reading, the $19^{\text {th }}$ century scientific report is read from the theory of displacement of the ideas of Philosopby of As If (Philosophie des Als Ob, 1911), by Hans Vaihinger, with elements of Wolfgang Iser (fictional, imaginary) and Vilém Flusser (philosophical fable Vampyrotheutis Infernalis). In this reading, descriptions of alternating zoology by Guimarães Rosa and Wilson Bueno, a poem by Fritz Müller and a fragment of Galáxias, by Haroldo de Campos, are counterpoints that explore the limits between fiction and fact, and between fiction, hypothesis and scientific dogma. Keywords: Fritz Müller; Philosophy of As If; science; fiction; imaginary zoology 
Quando o naturalista-viajante Johann Friedrich Theodor Müller (1822-1897), Fritz Müller, explorou banhados das províncias do Sul do Brasil à procura de um verme descomunal, o Minhocão, os campos do dogma científico, da bipótese e da fiç̧ão se superpuseram. Pois, nos termos de Hans Vaihinger e sua 'lei do deslocamento das ideias', a extraordinária figura do anelídeo foi tomada in media res, porque, não sendo ficção, não sendo dogma, a configuração da anomalia animal era uma "representação sem validade objetiva", reconstituída apenas pelos talhos de relatos, ou seja, era uma hipótese, somente. No entanto, seu artigo "Der Minhocão"1 - publicado em 1877, na revista alemã Zoologische Garten -, embora concebesse a deriva da hipótese ao campo da ficção, não aboliu a possibilidade de que, se 'verificável', um filo, uma classe, uma ordem e uma família acolheriam o Minhocão. Nesse dilema, Fritz Müller o anotou como se ele desviasse os rios ou derrubasse tílias:

No planalto das províncias do sul do Brasil, nas cabeceiras do Uruguai e do Paraná, ouve-se falar de um maravilhoso animal gigante que vive sob a terra, chamado de Minhocão. Minhocão é o aumentativo de "minhoca" e em alemão pode ser traduzido como "Riesenregenwurm".

O que se conta a respeito desse minhocão é tão inacreditável que nos sentimos tentados a contemplar essa história meramente como fabulação vazia. Quem não iria sorrir com descrença ao ouvir falar de um verme com 30 braças $^{2}$ de comprimento e 3 de largura, revestido com uma couraça óssea rígida, capaz de dobrar ou derrubar grossos troncos de pinheiro (Araucaria brasiliensis) como se fossem folhas de grama, desviar o curso de riachos, ora convertendo terra seca em banhado intransponível, ora abrindo valas e secando banhados, por onde quer que abrisse seus caminhos?

Contudo, mesmo após verificação imparcial dos diferentes relatos sobre o minhocão, é difícil conseguir se deixar convencer de que realmente existe um animal de tamanho tão incomum habitando os amplos banhados que acompanham o curso de muitos afluentes menores dos já mencionados rios, mesmo se restringirmos esse tamanho a uma medida muito mais modesta do que sói exagerar a boca do povo, afeita ao maravilhoso ${ }^{3}$.

O Riesenregenwurm, de medidas imodestas, mereceu a verificação imparcial do autor que, em 1864, havia publicado um livro a favor do evolucionismo: Für Darwin. Então, pelo testemunho ocular dos informantes, Müller sumaria aparições

1 MÜLLER, Fritz. "Der minhocão" (1877). Fritz Müller: Werke, Briefe und Liebe. Abtellung 1: Arbeiten aus den Jabren 1844-1879, 2019.

2 A medida antiga Klafter correspondia à distância entre as pontas dos dedos de um homem com os braços estendidos horizontalmente, e variava de $1,80 \mathrm{~m}$ a $2,50 \mathrm{~m}$ dependendo da localidade [N.T.].

3 Ibidem, s./p. 
do Minhocão em Santa Catarina, Lages, às margens do Rio Caveiras; no terreno pantanoso irrigado pelo Rio Marombas; nas imediações de um riacho afluente do Rio dos Cachorros; e em especial na região de Curitibanos, com pessoas "que acorreram para ver as devastações perpetradas pelo Minhocão". Essa visiva do "maravilhoso", na expressão de Fritz Müller, ainda se daria na província do Paraná, nas imediações do Rio dos Papagaios, afluente do Rio Iguaçu, e na de São Paulo, "não longe de Ipanema do Campo do Tinga", localidade de Charquinho. A toponímia precisa, ao modo de João Guimarães Rosa, sobre-exalta no relato um estatuto de veracidade e a "fabulação vazia" é contradita pelo teve lugar em.

E, no entanto, o animal inacreditável é lido apenas por indícios, reconstituindose, fragmentariamente, pelo 'depoimento' de cada um dos informantes ${ }^{4}$. Há quem o tenha inferido pelas valas de três metros de largura num "caminho todo revolvido, torrões de terra jogados para os lados, e o terreno revolvido havia desmoronado (...)" ou quem o tenha antevisto, nos charcos, em "sinuosas valas em formato de cobra". Ou o rastro do Minhocão é adivinhado - pois "o caminho desse animal passava sempre sob a terra e abaixo do leito do riacho; várias tílias foram derrubadas e se partiram ao caírem sobre o solo irregular" - ou é mensurado com 1 metro de largura, pela distância entre as bordas da terra cavoucada. Consta que certo Francisco Amaral Varellas o avistou com focinho de porco; e que "o aparecimento do Minhocão precedia um longo período de chuvas"; e que o estrondo e, depois, o turvamento das águas do rio eram atribuídos ao ser insólito:

\footnotetext{
Especula-se que ainda esteja vivo no banhado cuja água às vezes se turva repentinamente sem razão aparente; sim, em noites de quietude alguns dizem ouvir às vezes no banhado um rugido abafado, como de um trovão distante, e percebem um leve tremor no piso da casa! ${ }^{5}$.
}

\footnotetext{
4 Em um breve registro de Criptozoologia, uma ciência de ficção, Mathew J. Eaton comenta que o Minhocão tem sido relatado nas florestas da América do Sul desde o século XIX: é animal escavador gigante, com até 75 pés de comprimento, pele escamosa preta e duas estruturas semelhantes a tentáculos na cabeça. Segundo Eaton, uma primeira referência ao Minhocão foi feita em artigo de Auguste de Saint-Hilaire publicado no American Journal of Science (que o descreve na província de "Goiaz", predando e arrastando gado para o fundo dos rios). Na sequência, ele reproduz excertos de Fritz Müller. Também menciona os pesquisadores contemporâneos que supõem o Minhocão extinto há 130 anos, ou divergem, o associando a anacondas gigantes, ou a minhocas de 3 metros, espécies endêmicas da Austrália (embora minhocas não sejam predadoras), ou a uma espécie sobrevivente do gliptodonte do Pleistoceno, ou ao lepidosireno (peixe-serpente sul-americano) de proporções aumentadas. Para Eaton, a hipótese mais "verificável" seria a de um verme; também cita a teoria de Karl Shuker de que o animal seria a serpente anfíbia da ordem dos Cecilianos (Caecilian). Página original inativa, com conteúdo integral reproduzido. Disponível em: https://www.meta-religion.com/Paranormale/Cryptozoology/Other/minhocao.htm.

5 Ibidem, s./p.
} 
Hans Vaihinger formula, em Filosofia do como se (Philosophie des Als Ob, 1911) - o extenso tratado de positivismo idealista, de feição kantiana, que "se funda no dado, nas sensações empíricas, fatos e ideais" -, a teoria de que "ficções são formações psíquicas; a própria psique tece esses meios auxiliares" ", citando, entre outras representações, a ideia do absoluto, uma fiç̧ão científica que se inscreveria na "teoria das representações conscientemente falsas, porém úteis" ", a exemplo das ideias de imortalidade e de Deus, para ele "justificadas e necessárias" no horizonte da Ética. Trata-se de abarcar toda a "natureza polifônica" pelo estreitamento da teoria lógica, reduzindo o inapreensível a leis elementares e simples, servindo-se, nesse processo, da partícula como se, dupla conjunção, um instrumento de "transporte" (metáfora) que opera o "misterioso enlace de dois ou mais pensamentos"

E a distinção entre fição propriamente dita e semifiç̧ão, gêneros não de todo separados, mas interligados por formas transitórias, é estratégica para Hans Vaihinger:

Ficções propriamente ditas, no sentido mais rigoroso da palavra, são construções de representação que não apenas contradizem a realidade, também são contraditórias em si mesmas, por exemplo, o conceito do átomo, o da Ding an sich (coisa em si). Delas temos de distinguir aquelas construções de representação que contradizem exclusivamente a realidade dada, respectivamente dela divergem, sem ser contraditórias em si; a classificação artificial, por exemplo. Poderíamos chamar estas de semificções (Halbfiktionen) ${ }^{9}$.

Necessário à cena de leitura desse Minhocão de Fritz Müller é o capítulo XXVII da Parte B - Teoria lógica das ficções científicas, em que Hans Vaihinger apresenta a lei do deslocamento das ideias. Ele postula que, no decurso do desenvolvimento, as ideias percorrem estágios de dogma, hipótese e ficção, ou, no reverso, ficção, hipótese, dogma. Como dogmas, haveria "grupos de representações que são considerados a expressão da realidade", portanto, indubitáveis; e como hipóteses, as "representações sobre as quais impera uma dúvida acerca de sua validade objetiva", tendendo o dogma à homeostase (ele não cita esse termo; ressemantizo-o) e a hipótese à tensão da psique. Assim, à procura da estabilidade, a transição de uma hipótese a dogma seria cotidiana, mas transcorre de forma "ilícita", sendo comum a passagem de uma ficção a dogma sem a intermediação da hipótese; ao contrário, o deslocamento da ficção à hipótese, "pela semelhança externa que existe entre ambas construções", seria

6 VAIHINGER, Hans. Filosofia do como se, 2011. p. 123.

7 Ibidem, p. 91.

8 Ibidem, p. 88.

9 Ibidem, p. 129. 
o natural. Mas, causa de maior tensão psíquica, em uma verdadeira fição científica - a ideia do infinitamente pequeno, por exemplo - "trata-se de pressupor algo, a respeito do qual se é convencido de que não é assim: deve-se contemplar algo como se fosse assim

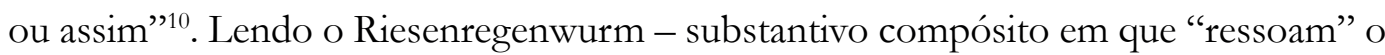
verme (wurm) grande (riesen), o verbo agitar (regen) ou o substantivo chuva (Regen) - pela teoria do deslocamento, a hipótese primeiro se imbrica na ficção, pois a oitiva da "boca do povo, afeita ao maravilhoso" (e "o povo é o inventalínguas na malícia da maestria no matreiro da maravilha no visgo do improviso", escreveu Haroldo de Campos) indica para Fritz Müller o inacreditável, decorrente não da figura, mas da sua desproporção:

\footnotetext{
Um homem jovem viu de repente uma grande tília cair sobre o campo. Não havia vento, e ele também não ouvira barulho de machado. Correu, então, para descobrir a causa da queda. Ao chegar, viu toda a terra em movimento, e saindo dela um enorme animal negro com aspecto de verme, "mais grosso que a mais grossa tília, mas não mais comprido que um laço" (cerca de 25 metros), com dois chifres móveis presos ao corpo perto da cabeça. (...) Certa manhã uma negra foi buscar água, contudo encontrou o charco inteiro destruído e viu se mover no chão a alguma distância um animal "grande como uma casa"".
}

Animal intersticial, habitante da área fronteiriça entre água e terra, o Minhocão participa da operação $A l s O b$ na medida em que é atestado - de uma a outra narrativa dos 'populares' - pela derrubada de araucária e tília como se o verme houvesse causado, ou como se turvasse as águas, por atravessá-las. Enlace entre duas ou mais causalidades, a representação do verme parece inconsciente (e falsa), mas era útil, no imaginário do Oitocentos, para fazer falar a realidade de uma terra incógnita, tropical/subtropical e, sobretudo, intempestiva à vida de colonos imigrantes. Tratava-se de abarcar a natureza polifônica pela figura elementar da minhoca descomedida - menos fabulosa do que aquela mboi tata (cobra de fogo) indígena; mais apropriada à semificção de uma História Natural aberta. Como meio auxiliar para explicação dos mistérios geológicos, Der Minhocão surgiu na psique (imagino com Vaihinger) não como quimera, fantasia ou lenda, mas como fiçãa que logo foi tomada como hipótese para o desvio dos rios e o revolvimento das terras.

Entre ciência e insciência, o Minhocão era uma ideia. E então, na medida em que a espécie de monstro "não revelado ou reprimido, em suma, fora do conhecimento"12,

10 Ibidem, p. 286-288.

11 MÜLLER, Fritz. "Der minhocão” (1877). Fritz Müller: Werke, Briefe und Liebe. Abtellung 1: Arbeiten aus den Jabren 1844-1879, 2019.

12 BERTIN, Juliana Ciambra Rabe. "O monstro invisível: o abalo das fronteiras entre monstruosidade e humanidade". Outra Travessia, n. 22, p. 39, 2016. 
pois se dava a ver fugidio, mais e mais se avizinhava à captura na semificção dos sistemas artificiais da taxonomia. Fato é que Fritz Müller descrê, mas se viesse a capturar um espécime o fixaria essa fição no dogma da Evolução, como conclui o artigo de 1877:

\begin{abstract}
Os relatos tão escassos quanto pouco confiáveis a respeito do animal não permitem ter qualquer clareza quanto à sua aparência ou mesmo seu tamanho. Contudo, certamente pode-se supor que ele seja um enorme peixe pulmonado, um parente dos Lepidosirae e do Ceratodus. O focinho de porco também parece lembrar uma cabeça semelhante à do Ceratodus, enquanto os "chifres" presos ao corpo lembrariam membros anteriores semelhantes aos dos Lepidosirae, se é que esses relatos podem ter qualquer pretensão de confiabilidade. De todo modo, vai valer a pena continuar a perseguir o rastro do Minhocão e possivelmente capturá-lo para um jardim zoológico.
\end{abstract}

Segundo a lei da alteração das ideias (Ideenwandel), outra denominação da lei do deslocamento, no 'desenvolvimento orgânico' de cada uma delas haveria "épocas da história de vida" - período fictício, período hipotético e período dogmático ${ }^{13}$-, com uma deriva própria a cada partícula: na ficção que se torna dogma o como se vira porque ou de modo que; na ficção que vira hipótese, o como se vira $s e^{14}$. Vaihinger explica que "o pensamento nos conduz, por si só, a determinados conceitos ilusórios, assim como a visão produz necessárias ilusões óticas"15, e, entretanto, assevera que "o retorno ao como se nos reconduzirá à natureza" ${ }^{\prime 1}$.

Wolfgang Iser lê essa fórmula estrutural da ficção (como se) - sendo a ficção um "postulado inautêntico" - entendendo que a partícula da condicionalidade significa que "a condição por ela estabelecida é irreal ou impossível"17. Em oposição ao "saber tácito" da vida real (Lebenswelt), "a representação do sujeito enche de vida o mundo do texto e assim realiza o contato com um mundo irreal. Causar reações sobre o mundo seria então a função de uso produzida pelo como se"18. Iser, aliás, argumenta que, diante das certezas do saber tácito sobre a ficção versus a realidade, deve-se "buscar relações, em vez de determinar posições [de supremacia da realidade sobre a ficção ou da ficção sobre a realidade]"19.

13 VAIHINGER, Hans. Filosofia do como se, 2011. p. 291.

14 Ibidem, p. 289.

15 Ibidem, p. 300.

16 Ibidem, p. 85.

17 ISER, Wolfgang. O fictício e o imaginário. 2013. p. 183.

18 Ibidem, p. 47.

19 Ibidem, p. 34. 
Quanto à lei da gradação, argumenta que "a história da ideia é a das condições psicológicas: no dogma, a realidade é identificada com a ideia; na hipótese, a ideia se torna uma pressuposição a ser verificada; na ficção, por fim, opera a consciência de que a ideia é o Outro radical daquilo a que se refere". Nesse escopo, a consciência (que, para ele, se determina por operações fingidoras e o estatuto de "pressuposições") se entrelaça à epistemologia ${ }^{20}$, isso porque toda ideia requer critérios de cognoscibilidade. Assim, para Wolfgang Iser, "o entrelace [i.é., o como se] significa que, em cada ficção, deve estar inscrita a consciência de ser ficção"21. No constructo do anelídeo procurado por Fritz Müller, a vida real impõe a ideia do Minhocão como dogma (porque o verme de 60 metros é "expressão da realidade" e cada um dos entrevistados apresenta seu testemunho e suas "provas"), mas o cientista a toma em seu período ficcional e, na investigação, a transforma em hipótese. Dito de outro modo, essa espécie de "crença ancestral" é convertida em factum pelos habitantes dos planaltos, mas o zoólogo a toma como fictum, como ficção. Pela dubiedade do objeto, a ideia do Minhocão participa, ao mesmo tempo, desses três estágios, deslocando-se, por esse perspectivismo, da "forma mítica de representação" ao animal de jardim zoológico. No rastro dessa deriva, o animal desconhecido obriga novos meios de cognoscibilidade.

Um meio "científico" de cognoscibilidade, a taxonomia era um dos fundamentos da Zoologia do Oitocentos: toda uma classificação fundada na morfologia comum dos seres. Assim, a tarefa do zoólogo era a de inscrever cada "novo" animal no quadro sinóptico do mundo, pela "reorganização completa de todas as ciências naturais em consequência da teoria da evolução"22. Nessa semificção das classificações (como a Tabela Periódica dos Elementos, de 1859, ou a botânica de Lineu), Fritz Müller refutava - no capítulo "Sobre os princípios de classificação" do livro Für Darvin a embriologia de fins do XIX (Johannes Müller e Louis Agassiz, principalmente), em sua tentativa de "encontrar o fio condutor pelo emaranhado das formas de desenvolvimento ora tão distintas em parentes próximos, ora tão espantosamente parecidas em grupos distantes." 23 Ele propunha um "sistema verdadeiro e natural" para a classe dos Crustacea, refeito conforme a sequência de aparecimento de fenômenos, considerando-se os modos de segmentação, a posição do embrião e o número de

20 Ibidem, p. 183.

21 Ibidem, p. 184.

22 Em "Como nasceu a Filosofia do como se", Hans Vaihinger relata o contributo da concepção mecânica na sua filosofia do Als $\mathrm{Ob}$ e, em particular, menciona Darwin e a "sua forma especial de teoria da seleção, isto é, da seleção mecânica, automática, do mais útil pelo que é chamado de 'luta pela existência”. (...) (VAIHINGER. Filosofia do como se. 2011. p. 684).

23 MÜLLER. Für Darwin. 2009. p. 129. 
apêndices produzido dentro do ovo ${ }^{24}$. Ao deslocar categorias de subclasses e ordens da Zoologia, criava conscientemente outra ficção para a taxonomia - um outro como se.

Se no quadro da evolução das espécies (species) é a partir da "aparência externa" (morfologia) que há classificação, cabe abrir essa leitura a um verso das "Metamorfoses" $(15,253)$, de Ovidio, citado por Erich Auerbach no livro Figura ${ }^{25}$ : ex allis alias reparat natura figuras (a natureza recria as formas umas a partir das outras). Então, para Fritz Müller, a própria figura do Minhocão classifica-se como se fosse peixe pulmonado: sendo Ceratodus, ou sendo Lepidosirae, a forma (figura) é "metamorfoseada" a partir de anelídeos ancestrais. Tratava-se, entretanto, de reduzir o inapreensível a uma figura elementar, classificável (confinada em jardim zoológico) e subsumida a uma palavra de terminologia erudita - o "maravilhoso" e desconhecido a ser capturado pelo nominalismo.

Nessa deriva, o Minhocão terá sobrevida apenas no "mundo do texto", deslocado como ideia à condição de ficção, porque, nem Lepidosirae, nem Ceratodus, a hipótese aventada por Charles Darwin - numa carta a Fritz Müller datada de 9 de maio de 1877 - é a de um anódino roedor sul-americano. $\mathrm{O}$ autor de $A$ origem das espécies conjetura:

(...) Com respeito ao grande animal supostamente subterrâneo, a crença [grifo meu] não poderia ter surgido pelo fato de os nativos terem visto grandes esqueletos embutidos em rochas? Lembro de achados nos bancos do Paraná do esqueleto de um Mastodon, e os gaúchos concluíram que ele era um animal escavador como o Bizcach $a^{26}$.

Em suas pesquisas na praia da Armação da Piedade, Santa Catarina, Fritz Müller encontraria, em 1885, um exemplar "gigante" de hemicordado da classe

24 Ibidem, p. 137.

25 Em Figura, Erich Auerbach retoma a formação do conceito na antiguidade pagã e afirma que figura (forma plástica) provém da mesma raiz de fingere, figulus, fictor e effigies. No longo percurso semântico, do conceito de forma dos Gregos - morphè, eidos, schèma, typos, plasis - à teoria dos tropos e das figuras de Retórica de Quintiliano, observa que schèma significava 'aparência externa' na terminologia erudita grega, sendo corrente o termo figura em Latim. "Aparência externa" e "contorno" em Varrão, a palavra é transposta por Lucrécio para a esfera auditiva em figura verborum (a figura das palavras), que a emprega, ainda, no sentido de "visão de sonho, imagem da fantasia, fantasma". Em Cícero, seu uso é extremamente flexível. Historicamente, figura expandiu-se à acepção de "estátua", "imagem”, "retrato", documenta ele, "a ponto de usurpar o domínio de statua e até de imago, effigies, species, simulacrum (imagem, efígie, figura, simulacro)". Para ele, "figura é mais dinâmico do que forma" (AUERBACH, Erich. Figura, 1997, p. 13-26). 26 ZILLY. Dear Mr. Darwin. 1997. p. 201. 
Enteropneusta - pequeno animal marinho que se alimenta de sedimentos e vive em galerias subterrâneas rasas em regiões de entre-marés -, medindo cerca de um metro e meio, classificado, em 1899, como Balanoglossus gigas ${ }^{27}$ : o termo gigas indica a desproporção no quadro da espécie.

O extinto ${ }^{28}$ ou inexistido Der Minhocão não teve lugar em nenhuma taxonomia, porque inverificável, mas "pervive" no século XXI como figura hipotética, ou como fato de fição.

Na proposição de uma antropologia literária, pressupondo-se que a atividade de “ficcionalizar é disposição humana”, Wolfgang Iser retoma o problema epistemológico dos começos da modernidade: "como pode existir algo que, embora existente, não possui caráter de realidade?" Recusando a literatura como um meio ou como "prova" de algo (no entretenimento, na informação, na documentação e passatempo), sustenta que "a literatura necessita de interpretação, pois o que verbaliza não existe fora dela e só é acessível por ela" 29 - e "o modo de enunciar é o que ocorre", como escreveu Barthes sobre Beckett.

Porque o mundo do texto não é idêntico ao do contexto (digamos, a "vida real"), a literatura se reporta, pela designação ou pela remissão, a um real (mundo extratextual) que the serve como campo de referência. O "acesso ao mundo" (Weltruwendung) se dá em "fragmentos reconhecíveis de realidade" ${ }^{30}$, quando "a realidade se repete no texto ficcional, mas essa repetitividade é superada por estar entre parênteses" ${ }^{\text {”1 }}$.Iser formula os atos de fingir por configurações diferenciadas, funcionalmente, em seleção (ato que deforma o campo referencial e produz a intencionalidade do texto), combinação (ato de relação de elementos intratextuais), e autoindicação, quando ocorre o "desnudamento da ficcionalidade na literatura", no jogo entre a empiria e a metáfora. Pelos atos de fingir se dá a transgressão de texto e contexto, sendo que, a partir do real, o fictício (que é um ato intencional e um objeto transicional) abre vias ao imaginário:

Como o texto ficcional contém elementos do real sem que se esgote na descrição deste real, seu componente fictício não tem o caráter de uma

27 SAWAIA, Paulo. "Reencontro de Balanoglossus gigas Fr. Müller no litoral brasileiro”. Boletim do Instituto Paulista de Oceanografia, vol.1, n.1, 1950.

28 Müller registra um dos boatos: "Em 1849, o senhor Lebino estava em viagem e chegou nas imediações de Arapeí, no Uruguai. Ali contaram-lhe que a poucas milhas do seu local de pouso havia um Minhocão morto. Ele teria entrado numa garganta rochosa estreita, ficado preso ali e assim encontrado a sua morte. Sua pele seria tão grossa como a casca de uma tília, composta de escamas duras como as de um tatu".

29 ISER. O fictício e o imaginário, 2013. p. 25.

30 Ibidem, p. 31.

31 Ibidem, p. 43. 
finalidade em si mesma, mas é, enquanto fingido, a preparação de um imaginário (die Zurüstung eines Imaginären) ${ }^{32}$.

O imaginário, terceira condição constitutiva do texto literário proposta por Iser, não é substância, é função e processo e se desenvolve na interação com o fictício, tendo feições diversas "em função de ser ativado pelo sujeito (imaginário como faculdade), pela consciência (como ato de ideação) ou institucionalização social (como imaginário radical)"33. “Criação contínua, sócio-histórica e psíquica, essencialmente não determinada, de figuras/formas/imagens que subjazem a cada fala de algo"34, o imaginário seria uma "alteridade do determinado" $"$.

E porque "ler visa introduzir em tudo o que se torna presente o que foi excluído" ${ }^{\text {36 }}$, na interação (ou contraposição) entre fictício e imaginário há o jogo entre "dois mundos", ativando-se o imaginário pelos atos de seleção, combinação e como se (autoindicação). Afirma Iser: "Pela autoindicação, o fingir se torna puro meio para o imaginário, que, sob essa forma, possibilita a imaginabilidade do invisível" 37.

Por essa imaginabilidade do invisivel, Vilém Flusser concebeu (com Louis Bec) a "fábula filosófica" de que o Vampyrotheutis Infernalis - uma espécie de Octopoda, do filo Mollusca, dotado de espiralidade, o ser retorcido sobre si - é o antípoda do homem. Ao contrário do Minhocão, esse animal abissal é verificável, com espécimes à mostra em aquários da Europa, mas, diante da inviabilidade de prospectar seu habitat marinho sob pressão absurda, Flusser capta "intuitivamente" (ou pelos atos de fingir) o ambiente da espécie talvez monstruosa que, segundo o filósofo, é um "ser-conosco" (Mitsein).

Concebendo o ensaio-fábula como "tentativa de criticar a nossa vida vertebrada do ponto de vista molusco" 38 , argumenta, no campo estrito da taxonomia, que "todos os Bilateria são vermes, inclusive o homem" (ibidem. p.16) e - no enlace de outro como se - que o ponto nodal da evolução das espécies é a minhoca, sendo "os Annelida ancestrais comuns a homens e Vampyrotheutis" ${ }^{39}$ :

\footnotetext{
32 Ibidem, p. 31.

33 Ibidem, p. 255.

34 Ibidem, p. 279.

35 Ibidem, p. 285.

36 Ibidem, p. 299.

37 Ibidem, p. 306.

38 FLUSSER. Vampyrotheutis Infernalis. 2011. p. 19.

39 Ibidem, p. 43.
} 
Se considerarmos a evolução vital como um todo, podemos distinguir nela três direções divergentes. Uma direção principal, que passa pelos Annelida rumo aos insetos. Uma direção lateral, que se separa da principal antes dos Annelida, e que avança rumo ao homem. E, outra direção lateral, que se separa da principal depois dos Annelida, e avança rumo ao Vampyrotheutis. Se visto assim, é ele o nosso antípoda, não apenas de maneira geográfica e existencial, mas também filogeneticamente ${ }^{40}$.

Seres pensantes $a \mathrm{abos}^{41}$, as semelhanças entre homem e cephalopoda se aprofundam no fato de que temos olhos (fotográficos) iguais, que "somos seres erguidos" e, portanto, assumimos a posição vertical e de que pertencemos ao mesmo infra-reino dos Coelomata. Dotados de ectoderma, endoderma e mesoderma, os tecidos pelos quais "somos animais que se distinguem do mundo, que se orientam no mundo, que agem sobre o mundo, e que o absorvem", argumenta, “os Eucoelomata são animais que seriam inacreditáveis, se não fôssemos nós próprios Eucoelomata" ${ }^{42}$. In extremis, "somos alienados do chão", enquanto os Vampyrotheutis são "alienados do céu" ${ }^{43}$.Entretanto, é como se o "Vampyrotheutis fosse o lado reprimido do homem":

(...) Darwin concebe a evolução como luta pela sobrevivência das espécies e pela sobrevivência do indivíduo dentro da espécie. "Dialética da liberdade". É o modelo do Vampyrotheutis. A vida aparece como o monstro canibal e suicida que devora seus próprios tentáculos. Cada ser vivo devora outro ser vivo para ser devorado por outro ser vivo. O canibalismo é o próprio mecanismo da evolução, do "progresso". O fratricídio é o método pelo qual o espírito vai se impondo sobre a natureza. Porque o espírito é a melhor arma em tal luta de todos contra todos. Pois tal modelo odioso é o próprio modelo da liberdade e produto do pensamento responsável pelo liberalismo. E o que foi dito com referência ao modelo darwiniano, vale para todo o modelo sociopolítico humano. No fundo de todos eles, habita o Vampyrotheutis, reprimido, por certo, mas efetivo. É que o Vampyrotheutis não é o oposto do homem, mas o lado reprimido do homem $^{44}$.

Embora o "jogo permutatório do programa vital" possa vir a produzir monstros, rememora Flusser ${ }^{45}$, o Vampyrotheutis - dotado de pernas em torno da boca - é uma espécie inteligente, sendo ele o adversário, duplo reprimido do animal humano. As semelhanças infernais com o homem, aliás, perturbam a noção de espécie,

40 Ibidem, p. 28

41 Ibidem, p. 44.

42 Ibidem, p. 15-16.

43 Ibidem, p. 44.

44 Ibidem, p. 107-108.

45 Ibidem, p. 43. 
problema sempre posto às ciências naturais ${ }^{46}$, diante da probabilidade de cada "linha evolutiva" afluir em outra. Eis a hipótese de Flusser: "cada ser vivo é como um monstro amputado de todas as suas virtualidades, salvo as que o caracterizam" ${ }^{\prime 7}$. Assim, nessa não-ficção do Octopoda, "fragmentos reconhecíveis de realidade" dão acesso ao mundo, digamos, 'facultativo': embora verificável na realidade, parece não existir.

Em outra direção, os atos de fingir parecem dar a ver outra espécie de alteridade. Da ordem dos naturalistas-fantasistas - de Esopo a Raimundo Lúlio -, Guimarães Rosa investigou a (sobre)natureza animal no jardim zoológico da Quinta da Boa Vista, Rio; nos Parc Zoologique du Bois de Bologne e Jardin de Plantes, Paris; no Whipsnade Park, Londres; e no Hagenbecks Tierpark, Hamburgo. Das "observações de campo" derivam as enunciações de "Zoo", reunidas no livro póstumo Ave, palavra (1988), a exemplo da sua especificação da serpente (Chordata): "a serpente é solipsista, escorreita perfeita, no sem murmúrio movimento, desendireitada, pronta: como a linha enfiada na agulha" ${ }^{48}$. Considerando que sua definição precisa e em negativo - o movimento sem murmúrio - parece pertencer a outro sistema de classificação, com valor de verdade num mundo alterno, caberia antepor a descrição roseana uma questão levantada por Iser: “Os textos 'ficcionais' serão de fato tão ficcionais e os que assim não se dizem serão de fato isentos de ficções?" ${ }^{49}$.

Entre texto e contexto, entre empiria e metáfora, o zoo de Guimarães Rosa parte do mundo extratextual, mas deforma o campo referencial em uma seleção que, de saída, o configura como sátira, vide "O macaco, homem desregulado. O homem, vice-versa, ou idem" 50 , em que a combinação do pronome ‘idem' e do advérbio ‘viceversa' parece encerrar a comutação entre o homem e o macaco nos movediços da reincidência. Em uma realidade posta entre parênteses, o fictício faz a sua transição para o imaginário da matemática e ocorre um "desnudamento da ficcionalidade" pela figura da incógnita: "O macaco está para o homem assim como o homem está para x"51. Por último, em seis visitas ao zoo de Hamburgo (1938-1942), alcança o imaginário da guerra: "Se todo animal inspira sempre ternura, que houve, então, com o homem?" 52 . Da espécie dos apólogos, esses textos “ficcionais" de Rosa serão de fato tão ficcionais?

\footnotetext{
46 Ibidem, p. 54-55.

47 Ibidem, p. 132.

48 ROSA. Ave, palavra. 1988. p. 68.

49 ISER, W. O fictício e o imaginário, 2013. p. 31.

50 Ibidem, p. 124.

51 Ibidem, p. 125.

52 Ibidem, p. 122.
} 
Nessa cena de leitura dos animais "feitos" e animais "de fato", do deslocamento das ideias e dos atos de fingir, cabe evocar a insciência das classificações "fictícias": Wilson Bueno, fabulista da linhagem de Jorge Luis Borges e Augusto Monterroso, concebeu novas classificações e o fictício da sua operação de reconto instaura o imaginário do livro Jardim zoológico (1999). No bestiário ${ }^{53}$ povoado por seres imaginários como as anagiraldes - minhocas putrefatas extraídas do Trilce, de Vallejo -, pelo tarântula - um desenho à margem do manuscrito d'A metamorfose de Kafka - pelas cobras Yararás e pelo Ivitú do Chaco paraguaio - o animal capaz de "mitigar a saudade amorosa, mas não a dos que morrem" -, Jardim zoológico exacerba a autoindicação (a função como se dos atos de fingir para Iser) nas tramas de um vasto tecido intertextual que sutura séculos. E ainda que o contexto antropológico das fábulas que Bueno reconta (há o imaginário dos Guarani, por exemplo) deixe entrever o mundo extratextual, o que ocorre ocorre na enunciação e, pelo fictício das representações, todo o bestiário faz falar o imaginário da solidão animal (entre os viventes nas celas do jardim zoológico ou nas regras para o parque humano).

Por exemplo, na representação do cartógrafo Agamenão da Cunha do monstro marinho Agôalumen, uma figura comum ao gênero das "histórias trágico-marítimas", essa transgressão do contexto pelo mundo do texto instaura novas relações entre o real (das narrativas de "testemunho" do mundo naval quinhentista) e a ficção. O postulado inautêntico é autoindicado como ficção na coleção de zoologia outra:

\begin{abstract}
A crer nas crônicas lusitanas, não há nem haverá como o Agôalumen, ao modo de um impossível lagarto transmutado em dragão, animal transparente e da cor da água, a exibir, triunfante, seja no fantástico voo ou no mergulho ao fundo, o seu esplendor de água-viva, o cegante celofane de sua líquida textura e, dentro dele, no ventre do Agôalumen, feito um milagre proverbial e de grande generosidade, borbulhas e conchas, peixes e gerânios, hipocampos, imponentes arraias, o mistério de todo um mar de sargaços ${ }^{54}$.
\end{abstract}

O inumerável, a crer na existência do seu esboço na Biblioteca Nacional de Lisboa. O narrador seleciona uma hipótese para maior verossimilhança do seu relato: por que ele, o gigantesco, não faz naufragar as naus enquanto mergulha? Em outras palavras: ainda que o imaginário do maravilhoso permita o arroubo de um animal liquefeito, ao narrador está dada a necessidade de lastrear sua ficção em um fragmento

53 Wilson Bueno (1949-2010), autor da novela neobarroca Mar paraguayo (1992), publicou os bestiários Manual de zoofilia (1992), Jardim zoológico (1999) e Cachorros do céu (2005).

54 BUENO, W. Jardim zoologico, 1999. p. 29-32. 
de realidade, nesse caso, o problema do impacto do bicho descomedido sobre a superfície da água (essa a lição de Borges, quando argumentou que H. G. Wells não poderia ter ambientado o seu "homem invisível" em Marte, mas o fez contra um fundo da paisagem prosaica de Londres, para que o tornasse mais crível ao leitor). Então, pela combinação de termos oníricos com a ironia fina, Wilson Bueno alcança o imaginário feérico no mundo do texto:

\begin{abstract}
(...) Muito simples: segundo Agamenão da Cunha, tanto um adejar aos céus quanto nos retornos ao fundo do oceano, o Agôalumen, acreditem os céticos e os neófitos, os ateus e os tristes, os enterrados vivos pelo pesadume, não fazia nem som nem ruído nem alterava um cêntimo a superfície quieta das águas. Líquido e paina, pena e puro, mais um pouco flutuava, o Agôalumen, em sua delicadeza essencial, o mar no ventre feito nuvem, diáfano, quase invisível, com a graça bailarina de um sonho que se lançasse ao fundo ou se elevasse aos céus numa ascensão de névoa e vento ${ }^{55}$.
\end{abstract}

Como parêntese, cabe evocar que Fritz Müller, na série de doze poemas infantis (1859) sobre a fauna brasileira, escritos em Alemão para alfabetizar as suas nove filhas, concebeu o fundo do oceano (os mundos do Vampyrotheutis e do Agôalumen) como se dominado pelo silêncio, vide a última estrofe do poema "Seetiere" (animais marinhos):

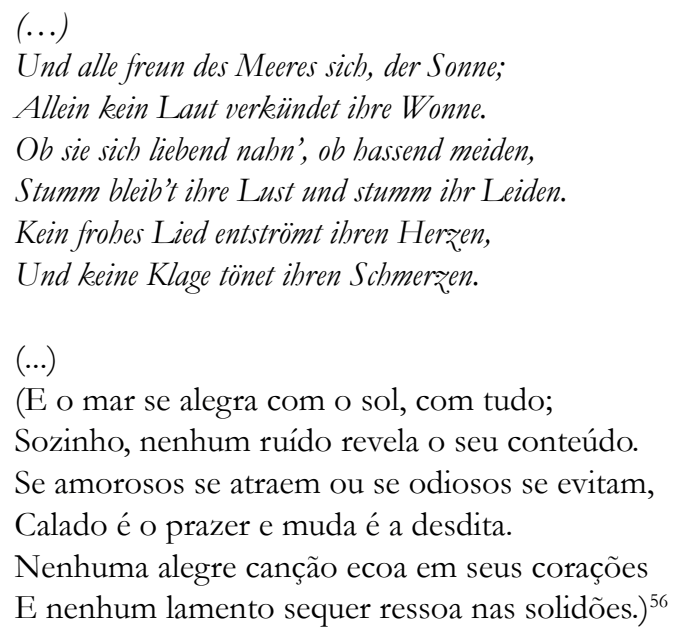

55 Ibidem, p. 29-32.

56 MÜLLER, Fritz. História natural de sonhos, 2004, s./p. 
E, então, com o mesmo gesto taxonômico de Rosa, Flusser e Müller, um outro verbete de Jardim zoológico retoma o como se daquilo que "existe, mas não possui caráter de realidade". É o caso de "Os sombras", o conto breve que exacerba a literatura como coisa "ficta" (coisa feita) e, retomando uma ideia pré-socrática como referência, descreve sua figura à contraluz de uma realidade empírica toda posta entre parênteses:

\begin{abstract}
Os sombras não existem.
Reside aí a singular natureza destes monstros dotados de braços e pernas e cabelos e que tendo se convertido numa suposição encantada andam à nossa órbita modesta como se existissem.

Anteriores ao tempo que é apenas o simulacro despedaçado da eternidade, os sombras, embora não existam, são bichos puros e, não raro, obsedantes. Mas se não existem nem nunca existiram, como conferir a eles um status de coisa viva, dotada de braços, pernas, cabelos e um secreto ritmo? Para os eleatas, que tinham o feio hábito de prender os sombras em câmaras escuras, se eles existissem, os homens e as coisas não existiriam. E explicavam o aparente paradoxo com uma exortação simples atentemos para eles, os sombras, que, se constituindo em nossas visagens, andam conosco e nos perseguem, inexatos desenhando-nos as formas no chão, nos muros, pelas paredes.

Deixar que existam é permitir que sejamos deles apenas um cambiante reflexo ${ }^{57}$.
\end{abstract}

Bichos puros, os sombras, agôalumen, serpente, minhocão, embora não existam, são as figuras que subjazem a fala de si? E o Vampyrotheutis Infernalis é animal impuro por que existe? Disjunção aparente, porque, ao modo de Gertrude Stein, o significante aponta a outro significante: o bicho é um bicho é um bicho é um bicho é um bicho é um bicho é um bicho é um bicho é um bicho é um bicho é - todo objeto é inapreensível?

Da classe de uma incógnita, " $\mathrm{x}$ " - vide o enunciado de Rosa sobre o homem -, uma operação extrema de classificação transcorreria pelas mãos do patologista Thomas Stoltz Harvey, que removeu, pesou e preservou o cérebro do físico Albert Einstein, dissecando-o em 240 seções. Em “O cérebro de Einstein”, Roland Barthes para quem "o mito é uma fala" - observa que "A mitologia de Einstein transforma-o num gênio tão pouco mágico que se fala do seu pensamento como de um trabalho funcional análogo à confecção mecânica das salsichas, ao moer do grão ou à trituração dos minérios" 58 . Pela capacidade "anormal" de traduzir toda a natureza polifônica em uma fórmula quase total (afinal, inalcançada, mas postulada como se pudesse vir a 
ser), o patologista supôs que, dissecando-se Einstein (a parte suprema de Einstein), a imaginação científica seria situada, verificável, talvez reprodutível. E o cérebro restou animalizado, em estado de museu, na fiçãa de uma hipótese localizacionista dos "dons":

A produção de equações era o que se esperava dessa mecânica genial. Através da mitologia de Einstein, o mundo reencontrou, deliciado, a imagem de um saber formulado. E - fato paradoxal - quanto mais o gênio do homem se materializava em seu cérebro, tanto mais o produto da sua invenção atingia uma condição mágica, reencarnava a velha imagem esotérica de uma ciência enclausurada em algumas letras. Existe um único segredo no mundo que cabe numa só palavra: o universo é um cofre cuja combinação o homem procura. Einstein quase a descobriu, eis o mito de Einstein; aí se encontram todos os temas gnósticos: a unidade da natureza, a possibilidade de uma redução fundamental do mundo, o poder de abertura da palavra, a luta ancestral entre um segredo e uma expressão, a ideia de que o saber total pode descobrir-se bruscamente como uma fechadura que cede após mil tentativas infrutuosas. A equação histórica $\mathrm{E}=\mathrm{mc} 2$, pela sua simplicidade inesperada, quase concretiza a pura ideia de chave, una, linear, feita de um só metal, abrindo com uma facilidade máxima uma porta contra a qual desde séculos nos desgastáramos. (... $)^{59}$.

Tornados ao início dessa cena de leitura, o Fritz Müller "de fato" - também ele à procura da chave nas vias e transvios da evolução - deriva como 'personagem' ao mundo do texto que o poeta Haroldo de Campos compôs, neobarrocamente, com a figura das galáxias:

59 Ibidem, p. 60-61.

fritz müller sonhando com bromélias o dr. fritz müller de thüringen erfurt com bromélias no delírio da febre in seiner fieberphantasien morto em blumenau em 1897 o ano do coup de des o dr. fritz müller leitor de feuerbach max stirner e marx quemsabe professor de cruz e souza com bromélias morte simbolista mais de quarenta cartas a darwin num espaço de 17 anos pesquisando crustáceos não para discutir e ponderar de novo as teorias de darwin quero dizer os prós\&contras mas para indicar alguns fatos o concreto não o abstrato gesammelt auf demselben boden sudamerika's colhidos no mesmo solo sulamericano onde darwin wie er uns erzählt como ele mesmo nos conta por primeiro concebeu a ideia de ocupar-se mit diesem geheimnis der geheimnisse com esse mistério dos mistérios a origem das espécies für darwin datado de desterro 7 de setembro de 1863 o dr. fritz müller-do-desterro como também se fizera conhecer traduzido para o inglês em londres 1869 por sugestão de darwin cartas também para agassiz em cambridge aquele mesmo do apólogo do peixe the sunfish ichtus heliodiplodokus agassiz and the post-graduate student contado por ezra pound olhe para o peixe olhe para o peixe olhe paraopeixe o jeito é olhar para o peixe o dr. fritz müller sabia olhar trazido a sta. catarina por um microscópio náuplius de tetaclita 
porosa primeira muda vendo-se o cérebro em torno dos olhos de onde se originam os filamentos olfativos e posteriormente alguns delicados músculos da coifa oral ou esse jovem de sacculina purpúrea com as suas raízes o animal vermelho-púrpura as raízes de um verde-grama escuro a figura 65 desenhada de memória pois os animais que tomei por jovens de prótula se tornaram estranhos e os desenhei logo que notei a presença do opérculo e protestara contra a fórmula do juramento médico sicut deus me adjuvet et sacrosanctum ejus evangelium porque não queria ser médico na prússia dentro de um dado sistema dogmático ${ }^{60}$

O aforismo de Leibniz citado por Darwin, Natura non facit saltum (a natureza não dá saltos) parece encerrar essa cena de leitura como campo de espécies imbricadas: ou atos de fingir ou ideias deslocadas, a legibilidade da natureza sobrevém aos saltos. De um a outro Fritz Müller (o à procura do anelídeo e o delirante de bromélias), tudo são bipóteses, porque a deriva entre "fato" (factum) e "feito" (fictum) nunca cessa de converter o dogma científico em ficção e a ficção - a exemplo da Terra Plana - em "hverdade" biopolítica. Tomar o dado como hipótese, eis um princípio da ficção, eis um começo de ciência.

\section{Referências bibliográficas}

AUERBACH, Erich. Figura. Tradução de Duda Machado. São Paulo: Ática, 1997.

BERTIN, Juliana Ciambra Rabe. "O monstro invisível: o abalo das fronteiras entre monstruosidade e humanidade". Outra Travessia, n. 22. Especial O monstro à mostra: mostruário. Florianópolis: Programa de Pós-Graduação em Literatura/UFSC, , 2016.

BARTHES, Roland. Mitologias. 9. ed. Tradução de Rita Buongermino e Pedro de Souza. Rio de Janeiro: Bertrand Brasil, 1993.

BUENO, Wilson. Jardim zoológico. São Paulo: Iluminuras, 1999.

CAMPOS, Haroldo de. Galáxias. 3. ed. São Paulo: Editora 34, 2011.

CASTRO, Moacir Werneck de. O sábio e a floresta: a extraordinária aventura do alemão Fritz. Müller no trópico brasileiro. Rio de Janeiro: Rocco, 1992.

60 CAMPOS. Galáxias, 2015. s/p. 
EATON, Matthew J. “Minhocão”. Página original inativa. Disponível em: <https:// www.meta-religion.com/Paranormale/Cryptozoology/Other/minhocao.htm>. Acesso em: 09 mai., 2020.

FLUSSER, Vilém; BEC, Louis. Vampyrotheutis infernalis. São Paulo: Annablume, 2011.

ISER. Wolfgang. O fictício e o imaginário: perspectivas de uma antropologia literária. Tradução de Johannes Kretschmer. 2 ed. Rio de Janeiro: Ed.UERJ, 2013.

MÜLLER, Fritz. “O Minhocão”. In: MÖLLER, Alfred (org.) Fritz Müller: Werke, Briefe und Leben. Abtellung 1: Arbeiten aus den Jahren 1844-1879. Tradução de Daniel Martineschen. Jena: Verlag von Gustav Fischer, 1914, 2019. (inédito).

MÜLLER, Fritz. História natural de sonhos/Naturgeschichte der Träume. Organização de Dennis Radünz. Tradução de Lia Carmen Puff e Dennis Radünz. Florianópolis: Nauemblu, 2004.

MÜLLER, Fritz. Para Darwin (Für Darwin, 1864). Tradução de Luiz Roberto Fontes e Stefano Hagen. Florianópolis: Ed. da UFSC, 2009.

ROSA, João Guimarães. Ave, palavra. 3. ed. Rio de Janeiro: Nova Fronteira, 1985.

SAWAIA, Paulo. "Reencontro de Balanoglossus gigas Fr. Muller no litoral brasileiro". Boletim do Instituto Paulista de Oceanografia, vol.1, n.1, São Paulo. Jun., 1950. Disponível em:

$<$ https://www.revistas.usp.br/bipoce/article/download/78732/82784>. SOUZA, Flavia Pacheco Alves de; SANTOS, Andrea Paula Kamensky; FONTES, Luiz Roberto. "Entre a ciência e o folclore: relatos do Minhocão coletados por Fritz Müller”. s/r. Anais do $9^{\circ}$ Congresso em História das Ciências e das Técnicas e Epistemologia, Scientiarum história IX, UFRJ, 2016. Disponível em: http://www. hcte.ufrj.br/downloads/sh/sh9/SH/trabalhos\%20orais\%20completos/ENTRE-ACIENCIA-E-O-FOLCLORE.pdf. Acesso em: 18 set. 2019.

SOUZA, Eneida Maria de. "O escritor vai ao zoológico". In: MACIEL, Maria Esther (org.). Pensar/ escrever o animal: ensaios de zoopoética e biopolitica. Florianópolis: Editora da UFSC, 2011. 
VAIHINGER, Hans. A filosofia do como se: sistema das ficções teóricas, práticas e religiosas da bumanidade, na base de um positivismo idealista. Tradução de Johannes Kretschmer. Chapecó: Argos, 2011.

ZILLY, Cesar. Dear Mr. Darwin: a intimidade da correspondência entre Fritz Müller e Charles Darwin. São Paulo: Sky/Anima, 1997.

Submissão: $17 / 05 / 2020$

Aceite: $10 / 08 / 2020$

https://doi.org/10.5007/2176-8552.2020.e73749 